\title{
Editorial
}

\section{Insulin-like growth factors and pancreas beta cells}

\author{
T.W. van Haeften and Th. B. Twickler \\ University Medical Center, Utrecht, the Netherlands
}

\begin{abstract}
Insulin-like growth factors (IGFs) have been implicated in normal growth, and especially foetal pancreas beta-cell development. As low birth weight has been implicated in the development of obesity and type 2 diabetes, much research has evolved into the importance of IGF and their signalling pathways for pancreas beta-cell development, and for type 2 diabetes. Insulin-like growth factor-I signalling has a lot in common with insulin signalling, and is involved in diverse cellular effects such as antiapoptosis, protein synthesis, cell growth and mitogenesis. Insulin-like growth factor-II can be bound by the insulin receptor A subtype and the IGF-1 receptor, which may explain its antiapoptotic effect.

Various knock-out model studies indicate that absence of IGF-I or the IGF-1 receptor is critical for foetal and postnatal growth. Similarly, knock-out models of post-receptor molecules (such as IRS-2) point to the physiological role of IGFs for pancreas beta-cell development. A beta-cell-specific IGF-1 receptor knock out model indicates the importance of IGF-I for beta-cell function. The Goto-Kakizaki (GK) rat, a model for diabetes, has insufficient beta-cell development, which may be related to its defective IGF-II synthesis.

As normal pancreas beta cells adapt to the prevailing insulin resistance with increasing beta-cell function, it is possible that insulin resistance interacts with IGF signalling in pancreas beta cells.
\end{abstract}

Keywords IGF-1, IGF-2, insulin secretion, type 2 diabetes.

Eur $\mathcal{F}$ Clin Invest 2004; 34 (4): 249-255

\section{Insulin resistance and beta-cell dysfunction}

The syndromes of both insulin resistance and type 2 diabetes have reached epidemic proportions in the West. Previously, most research regarding the pathophysiology of type 2 diabetes has been directed towards disturbances either in insulin action or in beta-cell function [1]. It now appears that both entities probably act together and that both are prerequisites for the development of diabetes [2]. The initial step in the development of type 2 diabetes mellitus is often considered to be peripheral insulin resistance [3]. Indeed, Pima Indians have been carefully studied, and nondiabetic offspring have been shown to be insulin resistant. Further studies have also revealed that the off-

Department of Internal Medicine, University Medical Center, Utrecht, the Netherlands (T. W. van Haeften, Th. B. Twickler).

Correspondence to: T. W. van Haeften, Department Internal Medicine G 02.228, PO Box 85500, NL 3508 GA, Utrecht, the Netherlands. Tel.: +31-30-2506256; fax: +31-30-2518328; e-mail: T.W.vanHaeften@azu.nl

Received 31 October 2004; accepted 9 March 2004 spring had a two- to three-fold increased insulin secretion, which is a sign of the strong adaptive mechanisms of the pancreas beta cells [4]. As subjects with type 2 diabetes often show abnormalities in beta-cell function, it was assumed that this adaptation could lead to 'exhaustion' of the beta cells with subsequent development of hyperglycaemia. In line with these observations, a decreased insulin secretion is the most important determinant in the development of type 2 diabetes mellitus in Pima Indians [2].

However, other carefully conducted studies revealed a decreased insulin secretion without insulin resistance in first-degree relatives of type 2 diabetes subjects, especially in Caucasian subjects $[5,6]$. However, also in Caucasians, insulin resistance remains one of the strongest predictors of (future) development of type 2 diabetes. The adaptation of insulin-secreting beta cells to sustained insulin resistance is therefore presumably a key factor in the control of glucose homeostasis.

The capacity of insulin-secreting cells is probably obtained in the prenatal period, and during the first year after birth. Interestingly, a low birth weight has been linked to later development of obesity, insulin resistance and type 2 diabetes mellitus, leading to the Barker hypothesis that foetal 
programming leads to later development of various diseases such as obesity and type 2 diabetes $[7,8]$. This sparked recent research of factors involved in the embryologic development of the pancreas. We will focus in this editorial on a possible role of insulin-like growth factors (IGFs) for the development and function of the pancreas islet. Recent results suggest that these factors initiate a number of pathways concerning cell maturation and differentiation, after binding to their target cells. These pathways have been described in more detail in various reviews [9-13].

\section{Insulin-like growth factors}

Insulin-like growth factors-I and -II share some homology with each other and with insulin. This has some physiological relevance because they may bind to several receptors. Insulin- and IGF-receptors belong to the protein tyrosine kinase receptor family. The insulin-receptor and the IGF-1 receptor are homologous, and can bind both ligands (that is insulin and the IGF). In addition, the IGF-1 receptor has binding sites for IGF-II, which are presumably separate from the IGF-I binding sites. Insulin-like growth factor-II has also some homology with insulin. As the IGF-2 receptor (also known as the mannose-6-phosphate receptor) has little homology with the other receptors, it can only bind to IGFII. Inversely, IGF-II can also be bound by insulin A-subtype receptors in addition to $\mathrm{IGF}-1$ receptors.

Most IGF-I and IGF-II is produced locally within the tissues where it has its action. In addition to this, IGF-I and -II are also available as circulating hormones bound to a number of binding proteins. Of note is that postnatal production of IGF-II increases gradually in humans, and plasma IGF-II levels are approximately three times higher than plasma IGF-I during adult life, while various rodents show little secretion of IGF-II after birth. Genetic influences on production of both IGFs is marked, as the variability of plasma expression of IGF-II is $66 \%$ genetically determined.

The IGF-1 receptor activates mitogenesis via pathways partially identical to insulin signalling. We will describe now some of the essential features of these signalling pathways.

\section{Insulin/IGF signalling}

\section{Insulin-receptor substrates}

Upon binding of insulin to extracellular domains of the insulin receptor, the signal transduction is mediated through intracellular beta-subunits that undergo autophosphorylation of tyrosine residues. After phosphorylation of these submembranous structures, a cascade of phosphorylations of so-called insulin-receptor substrates (IRS) starts [12,13]. Hitherto, four intracellular IRS (IRS 1-4) proteins have been isolated, and their distinctive IRS proteins direct to different intracellular pathways, while very recently two further IRS [-5 and -6] have been described [14]. In short,
IRS-1 regulates somatic cell growth and is involved in insulin activity of muscle and adipose tissue [15], and IRS-2 is involved in insulin activity mainly in the liver, brain growth, and reproduction, and is assumed to have an important role in pancreas beta-cell growth [16], as disruption of IRS-2 leads to loss of ability of beta cells to adapt to insulin resistance [17]. The pathways that are related to IRS-3 and IRS-4 remain unelucidated, but these IRS proteins are expressed in tissues of neuroendocrine and adipose origin. Insulin-receptor substrate- 3 and -4 disruption gives rise to normal (or even slightly lower) plasma glucose and normal insulin levels [12]. Insulin-receptor substrate-3 has been shown to be able to block some of the effects of insulinreceptor activation, notably on IRS-2 translocation to the plasma membrane, thereby reducing part of the subsequent signalling [18].

\section{Downstream signalling}

Upon phosphorylation of IRS proteins, the phospho-inositol 3-kinase (PI3-K) pathway is activated. This pathway consists of multiple subsequent phosphorylations, and gives rise to the expression of insulin's effects on glucose homeostasis [9]. Moreover, the signal transduction towards more downstream pathways of the PI3K pathway results in additional insulin-related effects, i.e. on protein synthesis, gene expression, mitogenesis, and cell growth. The PI3-K pathway involves phosphokinase $\mathrm{B}(\mathrm{PKB})$ and mammalian target of rapamycin (mTOR) activation [10], which ultimately lead to activation of a large number of transcription factors $[10,13]$.

The other well-characterized pathway upon stimulation of the insulin or IGF-1 receptor involves activation of Grb2, SOS, RAS, and MAPK.

The final pathways of insulin signalling include effects on transcription factors, part of which is described here: PKB (also known as Akt) is now known to regulate gene expression via inactivation of the transcription factor FKHR (forkhead in rhabdomyosarcoma, or FoxO1), which is a specific enhancer of the activity of signal translator and activator of transcription (STAT)-3-dependent promoters [19]. The PI3-K-PKB pathway has presumably an important role in regulating the cell cycle, as PI3-K mutants increase cell size by affecting p70S6 $\mathrm{k}$ and mTOR activity [20]. Mammalian target of rapamycin desinhibits the translation complex by its inhibition of the initiation factor 4E-binding protein (4E-BP1), and also activates p70S6 k. The latter will indirectly lead to translating ribosomal proteins and translation elongation factors, and induces cell size increase. While mTOR does not trigger cell division, PI3-K appears to have separate actions to induce cell division, and Alvarez et al. suggest that this may take place via cyclin D and $\mathrm{E}$ synthesis [19]. Phosphokinase B inhibits glycogen synthase kinase-3 (GSK-3), thereby decreasing beta-catenin activity which is a transcriptional activator in the cell nucleus [13].

The aforementioned activation of RAS by insulin/IGF will ultimately lead to activation of the MAPK isoforms extracellular regulated kinases (Erk)-1/-2, which translocate to the nucleus and promote transcription [13]. 


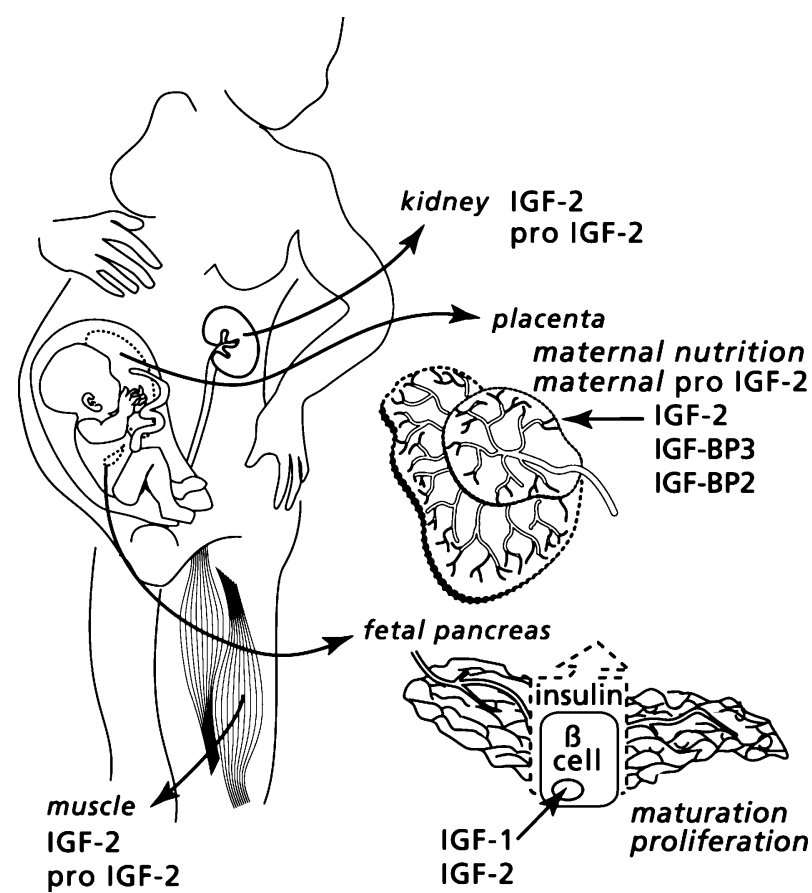

Figure 1 Influences of maternally derived Insulin-like growth factors (IGFs) on pancreas islet development during early foetal life.

\section{Apoptosis}

Phosphokinase B-activation also plays a role in the programmed cell death (apoptosis), and may have an antiapoptotic activity via inhibition of Bcl-2-associated death protein (BAD), at least in neurone cells [21] and $\mathrm{Mdm} 2$ [13]. One of the central phenomena in apoptosis is the translocation of $\mathrm{Bcl}$-associated $\mathrm{X}$ protein (BAX) to the mitochondrion, leading to caspase activation; BAX can be displaced from the antiapoptotic BCL-Xl by (proapoptotic) BAD.

Mdm2 targets p53 for proteasomal degradation; interestingly, Mdm2 associates physically with the IGF1R, leading to its degradation in the proteasome [22].

\section{IGF signalling}

\section{IGF-1 receptor}

Insulin-like growth factor-I mainly acts via the IGF-1 receptor (IGF-1r). The IGF-1r has structural homology with the insulin receptor, and upon its activation, as for insulin, partly identical transduction pathways are activated via IRS2, followed by activation of PI3-K and MTOR, but also of MAPK, leading to cell growth and mitogenesis. In tissues, IGF-I is capable of increasing cell numbers by inhibiting apoptosis (it inhibits the programmed cell death) [23]. Inhibition of apoptosis has been reported to depend on the

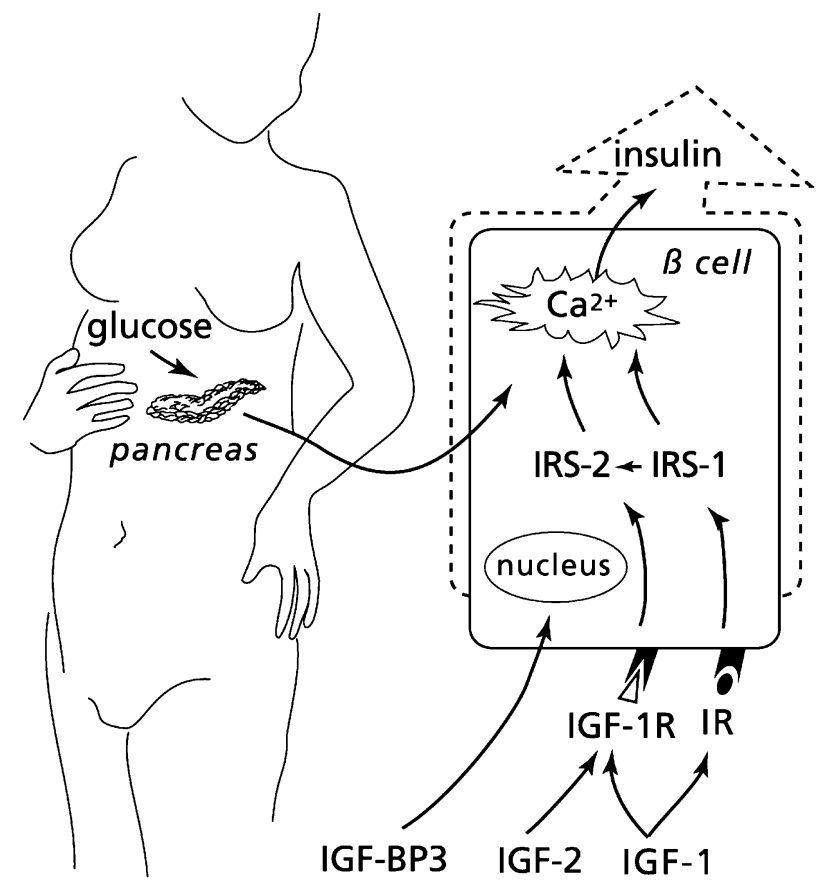

Figure 2 Influences of Insulin-like growth factors (IGFs) on pancreas B-cell function during later foetal life and during postnatal life.

I/IGF signalling pathways, notably via stimulation of PI3-K, leading to modulation of Erk-1/-2 and some of the PKC-alpha and -zeta, at least in chondrocytes [24]. Possibly, some of these effects depend on IRS-1, as an IRS-1 knockout model displayed much less IGF-1 prevention of caspase3 cleavage [25]. In neuroblastoma cells, IGF-I is capable of reducing caspase- 3 activation and cell death via PI3-K and Akt [26]. In other cell lines, IGF-I inhibits tumour-necrosis factor (TNF)-alpha-induced (antiapoptotic) nuclear factor kappa B (NF-KB) expression, also via PI3K [27]. Akt-related inhibition of STAT3 may also influence TNF-alpha gene expression [28]; this may possibly add to the reduction in $\mathrm{NF}-\kappa \mathrm{B}$ expression. In addition, IGF-1r activation also inhibits apoptosis signal-regulating kinase 1 (ASK1), which is independent of PI3K [29].

\section{IGF-2 receptor}

The IGF-2 receptor possibly has a role as a tumour suppressor [16], and binding of IGF-II leads to degradation of the growth factor. In one study, $\mathrm{GH}$ was capable of activating the promoter region of IGF-II gene [30], but the precise importance of GH-IGF-II interactions is unclear. As a result of cross reactivity with the IR type A and IGF-1r, IGF-2 exerts an antiapoptotic effect in various tissues, including pancreatic beta cells [31]. It is of note that IGF-binding proteins may stimulate apoptosis and may inhibit cell proliferation not only indirectly by binding IGFs but also directly, as IGFBP-3 mutants which could not bind IGF-I or -II are capable of inducing apoptosis in prostate cancer cells [32]. 


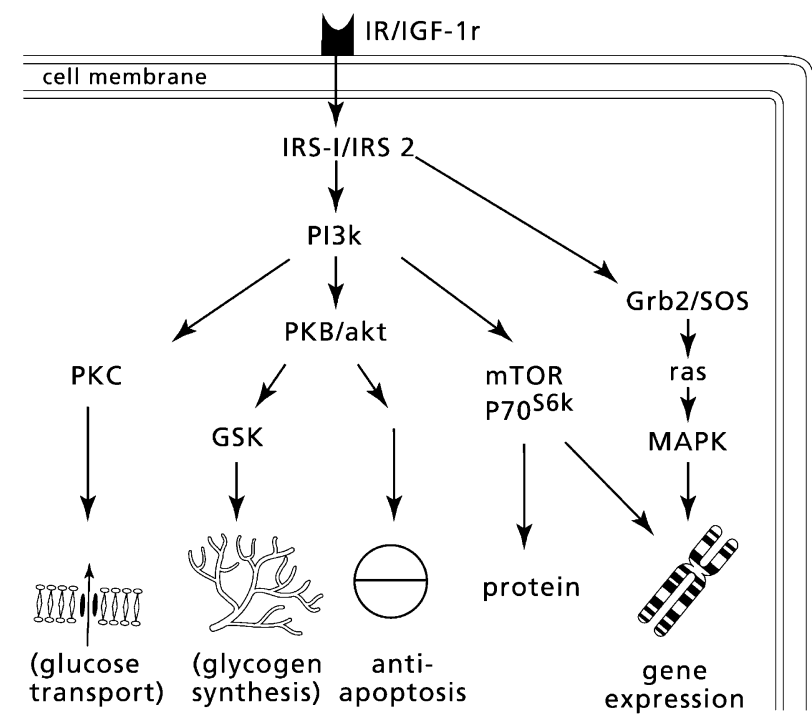

Figure 3 Schematic representation of various intracellular effects of I/IGF pathways in pancreas B cells.

\section{IGF and the pancreas: animal studies}

\section{Prenatal period}

During the prenatal period, the differentiation and maturation of many tissues including pancreatic beta cells are dependent on the interaction of growth factors, such as IGF-I and -II, which are major prenatal growth factors, and their cell-surface receptors (Fig. 1).

During the prenatal period, the differentiation and maturation of many tissues including pancreatic beta cells are dependent on the interaction of growth factors, such as IGF-I and -II, which are major prenatal growth factors, and their cell-surface receptors [33].

The origin of the development of pancreatic beta cells is a complex interaction of a large number of signalling molecules very early during pancreas development $[9,34,35]$. Insulin secretion in embryonic life is observed from as early as 4 months. Until 4 months' gestation, control of most growth factors that circulates in embryonic tissue is derived from maternal circulation. In this concept, plasma levels of IGF-I (a major factor in foetal growth) and IGF-II (a major growth factor that regulates differentiation of most mesodermal tissues, such as insulin-secreting beta cells) in embryonic life is a reflection of maternal genetic expression concerning IGF phenotype [36]. During the second trimester of pregnancy, the influence of the placenta as a tissue that secretes growth factors (such as placenta-derived growth hormone; $\mathrm{PdGH}$ ) gradually increases and from the 16th week to the last period of pregnancy, secretion of $\mathrm{PdGH}$ exceeds circulating $\mathrm{GH}$ secreted from the maternal pituitary $[37,38]$. In human subjects, $\mathrm{GH}$ modulates autonomous IGF-I secretion principally by the liver. Levels of IGF-I are related to antiapoptotic mechanisms. At birth, processes in pancreatic tissue such as an increase in apoptosis of beta cells with further maturation of remaining cells are observed. This increased apoptosis may be related to transfer of placenta-derived growth factors to newborn-derived growth factors. Variation of plasma levels in adult individuals is highly genetically determined (35\% for IGF-1 and $66 \%$ for IGF-2, respectively) [39]. Consequently, the developmental programme in which growth factors regulate the final insulin secretion capacity of the pancreatic beta cells is principally determined by its genetic expression, but is modulated by various growth factor-secreting tissues that govern during distinctive periods of early life [40].

\section{IGF-I in postnatal life}

Pancreatic beta cells are under the influence of growth factors not only during the prenatal period (Fig. 2). Also later in adult life, the influence of growth factors on the insulinsecreting cells is considerable. Especially, the involvement of the PI3K cascade in survival of pancreatic beta cells and the positive effect of MAPK activation on gene transcription show relationships between insulin-receptor-mediated and IGF-receptor-mediated effects with respect to beta-cell growth [9]. Although insulin-secreting beta cells are welldifferentiated in adult human life (less than $1 \%$ of pancreatic beta cells are in mitosis), they can still undergo proliferative changes [9]. Beta-cell proliferation is stimulated by IGF-I via the activation of the post-receptor IRS-2 proteins [41] (Fig. 3). In animal models, the IRS-2 knock-out mice have been shown to have not only impairment of insulin action, but also of beta-cell development, with consequent development of diabetes [17]. Those mice have a $60 \%$ reduction in pancreas islet cell mass with a relative beta-cell deficiency; the number of islets is also half that of normal. Transgenic mouse models have indicated that subsequent phosphorylation of PI3-K, Akt and mTOR are necessary for the transduction of this IGF-I signalling $[20,42,43]$; mouse models also showed that glucose has a modifying (stimulating) effect on the transduction of the IGF-I signalling [44]. Studies in knock-out models have shown that absence of IGF-I or the IGF-1 receptor is critical for foetal and postnatal growth [45]. Recent studies in mice with a beta-cell-specific knockout of the IGF-1 receptor indicate that the mice showed normal growth and development of beta cells but had a defective glucose-stimulated insulin secretion (with hyperinsulinaemia) and had impaired glucose tolerance. These studies indicate that even if IGF-1r is not crucial for isletcell development, it is of importance for beta-cell function [46]. Parenthetically, absence of insulin itself leads to enlargement of the islets without an increase in the size of individual beta cells with a lower incidence of apoptotic cells, again pointing to the importance of insulin/IGF signalling for apoptosis [47].

\section{IGF-II}

Much less is known about the role(s) of IGF-II in pancreas beta-cell mass and function. Insulin-like growth factor-II is 
known to have antiapoptotic properties. At least part of the effects of IGF-II may relate to its capability to bind to IGF1 receptors. Recently, it was found that the Goto-Kakizaki (GK) rat, which has been widely studied with it being a model for diabetes, displays defective IGF-II synthesis which may be causative for its insufficient beta-cell development [48]. However, transgenic mice overexpressing IGF-II develop frequent diabetes in spite of an increased beta-cell mass, possibly as a result of an increase in glucagonproducing alpha cells $[12,49]$. Pancreas cells are capable of producing IGF-II themselves [50].

Growth factors other than IGF are presumably also at play. Fibroblast growth factors (FGFs) have been proposed to have been implicated very early in the embryonic pancreas development [51]. In vitro studies suggest that they may influence the intestinal differentiation programme and the development of the dorsal and/or ventral part of the developing pancreas [52]. Fibroblast growth factors bind to extracellular FGF-receptors (FGFR), also belonging to the tyrosine kinase family. Recently, it was shown in in vitro studies that FGF7 could control the development of exocrine pancreatic tissue, while removal of the FGF7 led to proliferation of endocrine tissue [53]. Studies with transgenic mouse models expressing a dominant negative version of FGFR1 show that these animals develop diabetes [54]. These animal models not only have a reduced number of beta cells, but also an impaired expression of glucose transporter2 (Glut-2), the most prominent glucose transporter of both the pancreas and the liver. Moreover, the expression of PC1/3, prohormone convertase $1 / 3$, which is the enzyme catalyzing the final conversion of the prohormone proinsulin into the actual hormone insulin in the pancreas, is also decreased. Interestingly, the production of FGFs occurs in the beta cells themselves under the influence of other transcription factors, notably Ipf1/Pdx 1 , insulin-promoter factor-1 or pancreatic duodenal homeobox gene 1 . Ipf1 is known to stimulate insulin gene transcription and Glut 2 expression [31]. In humans, a nonsense mutation of the Ipf1 gene is a known cause of maturity onset diabetes of young type 4 (MODY4) [55].

\section{IGF and the pancreas: human studies}

Recently, several reports have mentioned the effect of disturbances in the expression of the IGF system on betacell function in humans in relation to glucose metabolism. A limited number of studies explore possible associations between plasma levels of the IGF system and insulin release; some investigate the presence of (common) IGF gene polymorphisms and insulin release.

\section{Relationship with IGF-I}

Presence of low plasma IGF-I levels has been associated with an increased risk to develop IGT and type 2 diabetes [56]. Both IGT and type 2 diabetes have been found to relate to a relative insufficiency of insulin secretion [57]. However, in hyperglycaemic clamps in normal-glucose- tolerant subjects, we did not find a relationship between plasma IGF-I and pancreas beta-cell function [58]. In view of the above-mentioned findings in IGF1-receptor knock-out mice [45], it could well be that the role of this polymorphism in insulin secretion is more subtle, and would only become apparent during the development of IGT. It is of note that the development of type 2 diabetes mellitus generally is the result of a combination of disturbances in insulin secretion and in sensitivity [57]. Therefore, it could also be that the role of IGF-I in the development of IGT might possibly relate to an effect of IGF-I on peripheral tissue insulin sensitivity.

Recently a very modest relationship was observed between an IGF-I gene polymorphism with (reduced) insulin sensitivity and an unclear effect on the Disposition Index, which is a measure of the adaptation of the pancreas beta-cell function to the prevailing insulin (in)sensitivity [59]. Followup studies may be of relevance to clarify this point.

\section{Relation with IGF-II}

Direct observations of the influence of IGF-II in humans are scarce. In recent studies in normo-glucose-tolerant human adults we could not find a relationship between variations in plasma IGF-II levels and measures of beta-cell function. However, more studies in this area are necessary. Of special interest may be the question of whether IGF-II may play a role in the adaptation of beta-cell function to certain events during life, such as development of insulin resistance and/or obesity, or pregnancy.

\section{Interference of insulin resistance with IGF}

As insulin and IGF have their signalling pathways partially in common, the possibility of reciprocal interference is raised. Under conditions of insulin resistance (obesity, pregnancy), pancreas beta cells may sharply increase their function, and sometimes also their mass. Whether IGFs are implicated in this phenomenon remains to be seen.

Interestingly, the effect of IGF-I on isolated (rodent) pancreas beta cells is glucose dependent. Although the antiapoptotic effect of IGF-I may be a factor necessary for the adaptation of beta cells to the strain of hyperglycaemia, prolonged hyperglycaemia has been associated with apoptosis, leading to decreased beta-cell mass [60]. However, recent studies have also pointed to a negative role for hyperlipidaemia and free fatty acids (FFAs) in this respect. Free fatty acids can activate Protein Kinase C (PKC) isoforms, some of which may reduce not only IRS-1 activity, but have also been proposed to inhibit IRS-2 [13], which is part of the insulin/IGF-signalling pathway. The latter effect might then interfere with IGF-1 receptor action, which would be in line with the observations that FFAs inhibit IGF-I induced activation of PKB, and that FFAs inhibited IGF-I-induced DNA synthesis [61]. As most hyperglycaemic subjects are also hyperlipidaemic, and as insulin resistance is known to lead to elevated levels of FFAs [62], it may be difficult to discern the effects of hyperglycaemia and FFAs. 


\section{Conclusion}

Taken together, animal studies showed a significant impact of growth factors, such as IGF-I and IGF-II, in the physiological development of prenatal pancreatic beta cells, and in adaptive properties of beta cells on environmental changes in the postnatal period. Insulin-like growth factor-I signalling has a major part in common with insulin signalling. In humans, the observation of a relationship between low birth weight and an increased prevalence of impaired glucose tolerance and type 2 diabetes has prompted research into the effect of the IGF system on (adult) insulin secretion and the occurrence of derangements of glucose homeostasis. Insulin-like growth factor-I levels have been shown to relate to the development of IGT. A major area of further research relates to the question of whether the impact of growth factors on the insulin secretion capacity in humans is limited to the prenatal period or whether it is also related to coping processes of the beta-cell in the post-natal period, such as during obesity, insulin resistance or pregnancy. Careful observational studies on the impact of obesity on onset of type 2 diabetes in subjects with polymorphisms of the IGFpathways are also necessary. The presence of polymorphisms may potentially lead to better defining subgroups in whom intervention could be more (or less) probable in order to lead to improvements of glucose homeostasis.

Hopefully, better knowledge about the IGF system may lead to novel preventive measures and/or therapeutic approaches in the future.

\section{Acknowledgement}

We gratefully acknowledge the superb artwork of Mrs Ingrid G. J. Janssen (Department of Multimedia, UMC Utrecht, the Netherlands).

\section{References}

1 Gerich JE. The genetic basis of type 2 diabetes mellitus: impaired insulin secretion versus impaired insulin sensitivity. Endocrine Rev 1998;19:491-503.

2 Weyer C, Bogardus C, Mott DM, Pratley RE. The natural history of insulin secretory dysfunction and insulin resistance in the pathogenesis if type 2 diabetes mellitus. $\mathcal{F}$ Clin Invest 1999;104:787-94.

3 Ferrannini E. Insulin resistance versus insulin deficiency in non-insulin-dependent diabetes mellitus: problems and prospects. Endocr Rev 1998;19:477-90.

4 Gulli G, Ferrannini E, Stern M, Haffner S, DeFronzo RA. The metabolic profile of NIDDM is fully established in glucose-tolerant offspring of two Mexican-American NIDDM parents. Diabetes 1992;41:1575-86.

5 Pimenta W, Korytkowski M, Mitrakou A, Jenssen T, Yki-Jarvinen H, Evron W et al. Pancreatic beta-cell dysfunction as the primary genetic lesion in NIDDM. Evidence from studies in normal glucose tolerant individuals with a first degree relative NIDDM relative. $7 A M A$ 1995;273:1855-61.
6 Van Haeften TW, Zonderland ML, Dubbeldam S, Erkelens DW. Insulin secretion in normal glucose-tolerant relatives of type 2 diabetic subjects. Assessments using hyperglycemic glucose clamps and oral glucose tolerance tests. Diabetes Care 1998;21:278-82.

7 Eriksson JG, Forsen T, Tuomilehto J, Jaddoe VW, Osmond C, Barker DJ. Effects of size at birth and childhood growth on the insulin resistance syndrome in elderly individuals. Diabetologia 2002;45:342-8.

8 Godfrey KM, Barker DJ. Fetal programming and adult health. Public Health Nutr 2001;4:611-24.

9 Rhodes CJ, White MF. Molecular insights into insulin action and secretion. Eur $\mathcal{f}$ Clin Invest 2002;32 (Suppl. 3):3-13.

10 Withers DJ, White M. Perspective:The insulin signaling system - a common link in the pathogenesis of type 2 diabetes. Endocrinology 2002;141:1917-21.

11 Yenush L, White MF. The IRS-signalling system during insulin and cytokine action. Bioessays 1997;19:491-500.

12 Burks DJ, White MF. IRS proteins and B-cell function. Diabetes 2001;50 (Suppl. 1):S140-5.

13 Lingohr MK, Buettner R, Rhodes CJ. Pancreatic B-cell growth and survival - a role in obesity-linked type 2 diabetes? Trends Mol Med 2002;8:375-84.

14 Cai D, Dhe-Paganon S, Melendez PA, Lee J, Shoelson SE. Two new substrates in insulin signaling. IRS5/DOK4 and IRS6/ DOK5. f Biol Chem 2003;278:25323-30.

15 Araki E, Lipes MA, Patti ME, Bruning JC, Haag BL, Johnson RS et al. Alternative pathway of insulin signalling in mice with targeted disruption of the IRS-1 gene. Nature 1994;372:186-90.

16 Rother KI, Imai Y, Caruso M, Beguinot F, Formisano P, Accili D. Evidence that IRS-2 phosphorylation is required for insulin action in hepatocytes. F Biol Chem 1998;273:17491-7.

17 Withers DJ, Gutierrez JS, Towery H, Burks DJ, Ren JM, Previs $S$ et al. Disruption of IRS-2 causes type 2 diabetes in mice. Nature 1998;391:900-4.

18 Lingohr MK, Dickson LM, Wrede CE, McCuaig JF, Myers MG, Rhodes CJ. IRS-3 inhibits IRS-2 mediated signaling in pancreatic beta-cells. Moll Cell Endocrinol 2003;204:85-99.

19 Kortylewski M, Feld F, Kruger KD, Bahrenberg G, Roth RA, Joost I et al. Akt modulates STAT3-mediated gene expression through a FKHR (FOXO1a)-dependent mechanism. F Biol Chem 2003;278:5242-9.

20 Alvarez B, Garrido E, Garcia-Sanz JA, Carrera AC. Phosphoinositide 3-kinase activation regulates cell division time by coordinated control of cell mass and cell cycle progression rate. F Biol Chem 2003;278:26466-73.

21 Henshal DC, Araki T, Schindler CK, Lan JQ, Tiekoter KL, Taki W et al. Activation of $\mathrm{Bcl}-2$-associated death protein and counter-response of Akt within cell populations during seizure-induced neuron death. F Neurosci 2003;22:8458-65.

22 Girnita L, Girnita A, Larsson O. Mdm2-dependent ubiquination and degradation of the insulin-like growth factor 1 receptor. Proc Natl Acad Sci USA 2003;100:8247-52.

23 Byrne AT, Southgate J, Brison DR, Leese HJ. Regulation of apoptosis in the bovine blastocyst by insulin and the insulin-like growth factor (IGF) superfamily. Mol Reprod Dev 2002;62:489-95.

24 Oh CD, Chun JS. Signaling mechanisms leading to the regulation of differentiation and apoptosis of articular chondrocytes by insulin-like growth factor-1. F Biol Chem 2003;278:36563-71.

25 Tseng YH, Ueki K, Kriauciunas KM, Kahn CR. Differential roles of insulin receptor substrates in the anti-apoptotic 
function of insulin-like growth factor-1 and insulin. $\mathcal{F}$ Biol Chem 2002;277:31601-11.

26 Saeki M, Maeda S, Wada K, Kamisaki Y. Insulin-like growth factor-1 protects peroxynitrite-induced cell death by preventing cytochrome c-induced capase-3 activation. 7 Cell Biochem 2002;84:708-16.

27 Vallee S, Fouchier F, Bremond P, Briand C, Marvaldi J, Champion S. Insulin-like growth factor-1 downregulates nuclear factor kappa $\mathrm{V}$ activation and upregulates interleukin-8 gene expression induced by tumor necrosis factor alpha. Biochem Biophys Res Commun 2003;305:831-9.

28 Chappel VL, Le LX, LaGrone L, Mileski WJ. Stat proteins play a role in tumor necrosis factor alpha gene expression. Shock 2000;14:400-2.

29 Galvan V, Logvina A, Sperandio S, Ichijo H, Bredesen DE. Type 1 insulin-like growth factor receptor (IGF-IR) signaling inhibits apoptosis signal-regulating kinase 1 (ASK1). $\mathcal{f}$ Biol Chem 2003;278:13325-32.

30 Von Horn H, Ekstrom C, Ellis E, Olivecrona H, Einarsson C, Tally $\mathrm{M}$ et al. GH is a regulator of IGF2 promoter-specific transcription in human liver. $\mathcal{F}$ Endocrinol 2002;172:457-65.

31 Hill DJ, Strutt B, Arnay E, Zaina S, Coukell S, Graham CF. Increased and persistent circulating insulin-like growth factor II in neonatal transgenic mice suppresses developmental apoptosis in the pancreatic islets. Endocrinology 2000;141:1151-7.

32 Hong J, Zhang G, Dong F, Rechler MM. Insulin-like growth factor (IGF)-binding protein-3 mutants that do not bind IGFI or IGF-II stimulate apoptosis in human prostate cancer cells. f Biol Chem 2002;277:10489-97.

33 Holt RI. Fetal programming of the growth hormone-insulinlike growth factor axis. Trends Endocrinol Metab 2002;13:392-7.

34 Dupont J, Holzenberger M. Biology of insulin-like growth factors in development. Birth Defects Res 2003;69:257-71.

35 Holland AM, Gonez LJ, Harrison LC. Progenitor cells in the adult pancreas. Diabetes Metab Res Rev 2004;20:13-27.

36 Jensen J. Gene regulatory factors in pancreatic development. Dev Dyn 2004;229:176-200.

37 Lacroix MC, Guibourdenche J, Frendo JL, Pidoux G, Evain-Brion D. Placental growth hormones. Endocrine 2002;19:73-9.

38 Lacroix MC, Guibourdenche J, Frendo JL, Muller F, Evain-Brion D. Human placental growth hormone - a review. Placenta 2002;23 (Suppl. A):S87-94.

39 Harrela M, Koistinen H, Kaprio J, Lehtovirta M, Tuomilehto J, Eriksson J et al. Genetic and environmental components of interindividual variation in circulating levels of IGF-I, IGF-II, IGFBP-1, and IGFBP-3. f Clin Invest 1996;98:2612-5.

40 Ball SG, Barber TM. Molecular development of the pancreatic beta cell: implications for cell replacement therapy. Trends Endocrinol Metab 2003;14:349-55.

41 Lingohr MK, Dickson LM, McCuaig JF, Hugl SR, Twardzik DR, Rhodes CJ. Activation of IRS-2-mediated signal transduction by IGF-1, but not TGF-a or EGF, augments pancreatic b-cell proliferation. Diabetes 2002;51:966-76.

42 Pende M, Kozma SC, Jacquet M, Oorschot V, Burcelin R, Le Marchand-Brustel Y et al. Hypoinsulinemia, glucose intolerance and diminished beta-cell size in S6K1-deficient mice. Nature 2000;408:994-7.

43 Cho H, Mu J, Kim JK, Thorvaldsen JL, Chu Q, Crenshaw EB et al. Insulin resistance and a diabetes mellitus-like syndrome in mice lacking the protein kinase Akt2 (PKB beta). Science 2001;292:1728-31.

44 Dickson LM, Lingohr MK, McCuaig J, Hugl SR, Snow L, Kahn BB et al. Differential activation of protein kinase B and
p70S6K by glucose and insulin-like growth factor 1 in pancreatic B-cells (INS1). F Biol Chem 2001;276:21110-20.

45 Liu J-P, Baker J, Perkins AS, Robertson EJ, Efstratiadis A. Mice carrying null mutations of the genes encoding insulin-like factor I (Igf-1) and type 1 IGF receptor (Igf1r). Cell 1993;75:59-72.

46 Kulkarni RN, Holzenberger M, Shih DQ, Ozcan U, Stoffel M, Magnuson MA et al. Beta-cell-specific deletion of the Igf1 receptor leads to hyperinsulinemia and glucose intolerance but does not alter beta-cell mass. Nat Genet 2002;31:111-5.

47 Duvillie B, Currie C, Chrones T, Bucchini D, Jami J, Joshi RL et al. Increased islet proliferation, decreased apoptosis, and greater vascularization leading to beta-cell hyperplasia in mutant mice lacking insulin. Endocrinology 2002;143:1530-7.

48 Serradas P, Lacome M, Gangnerau MN, Ramos S, Alvarez C, Pascual-Lane AM et al. Fetal insulin-like growth factor-2 production is impaired in the GK rat model of type 2 diabetes. Diabetes 2002;51:392-7.

49 Devedjian J-C, George M, Casellas A, Pujol A, Visa J, Pelegrin $\mathrm{M}$ et al. Transgenic mice overexpressing insulin-like growth factor-II in B cells develop type 2 diabetes. F Clin Invest 2000;105:731-40.

50 Bryson JM, Tuch BE, Baxter R. Production of insulin-like growth factor-II by human fetal pancreas in culture. $\mathcal{F}$ Endocrinol 1989;21:367-73.

51 Edlund H. Factors controlling pancreatic cell differentiation and function. Diabetologia 2001;44:1071-9.

52 Deutsch G, Jung J, Zheng M, Lora J, Zaret KS. A bipotential precursor population for pancreas and liver within the embryonic endoderm. Development 2001;128:871-81.

53 Elghazi L, Cras-Meneur C, Czernichow P, Scharfman R. Role for FGFR2IIIb-mediated signals in controlling pancreatic endocrine progenitor cell proliferation. Proc Natl Acad Sci USA 2002;99:3884-9.

54 Hart AW, Baeza N, Apelqvist A, Edlund H. Attenuation of FGF signalling in mouse beta-cells leads to diabetes. Nature 2000;408:864-8.

55 Stoffers DA, Ferrer J, Clarke WL, Habener JF. Early-onset type-II diabetes mellitus (MODY4) linked to IPF1. Nat Genet 1997;17:138-9.

56 Sandhu MS, Heald AH, Gibson JM, Cruickshank JK, Bunger DB, Wareham NJ. Circulating concentrations of insulin-like growth factor-I and development of glucose intolerance: a prospective observational study. Lancet 2002;359:1740-5.

57 van Haeften TW, Pimenta W, Mitrakou A, Korytkowski M, Jenssen T, Yki-Jarvinen $\mathrm{H}$ et al. Disturbances in B cell function in Impaired Fasting Glycemia. Diabetes 2002;51 (Suppl. 1):S265-70.

58 Twickler TB, de Sain-van der Velden MGM, van Doorn J, van Haeften TW. Association between IGF-I gene and low birth weight. (Letter) Lancet 2002;360:946.

59 't Hart LM, Fritsche A, Rietveld I, Dekker JM, Nijpels G, Machicao F et al. Genetic factors and insulin secretion. Gene variants in the IGF genes. Diabetes 2004;53 (Suppl. 1):S26-30.

60 Donath MY, Gross DJ, Cerasi E, Kaiser N. Hyperglycemiainduced beta-cell apoptosis in pancreatic islets of Psammomys obesus during development of diabetes. Diabetes 1999;48:738-44.

61 Cousin SP, Hugl SR, Wrede CE, Kajio H, Myers MG Jr, Rhodes CJ. Free fatty acid-induced inhibition of glucose and insulin-like growth factor-I-induced deoxyribonucleic acid synthesis in the pancreatic beta-cell line INS-1. Endocrinology 2001;142:229-40.

62 Eriksson JG, Forsen T, Tuomilehto J, Jaddoe VW, Osmond C, Barker DJ. Effects of size at birth and childhood growth on the insulin resistance syndrome in elderly individuals. Diabetologia 2002;45:342-8. 